\title{
ANALISIS KEBUTUHAN PETUGAS REKAM MEDIS DI KLINIK LARAS HATI SEWON BANTUL
}

\author{
Agung Kurniawan ${ }^{1}$, Rawi Miharti ${ }^{2}$, Yuliana Fatim ${ }^{3}$, Wilmince Sarina Sindang ${ }^{4}$ \\ Program Studi Manajemen Informasi Kesehatan, STIKes AKBIDYO ${ }^{1,2,3,4}$ \\ agungkurniawan991@gmail.com
}

\begin{abstract}
ABSTRAK
Latar Belakang: Analisis Beban Kerja merupakan upaya menghitung beban kerja pada satuan kerja dengan cara menjumlah semua beban kerja dan selanjutnya membagi dengan kapasitas kerja per orangan per satuan waktu. Klinik Laras Hati Sewon Bantul selama ini belum memiliki lulusan DIII Rekam Medis, sehingga klinik perlu menghitung dan mengadakan petugas rekam medis di Klinik Laras Hati dengan menggunakan Metode WISN

Tujuan Penelitian: Tujuan dari penelitian ini adalah Mengetahui kebutuhan Tenaga Rekam Medis di Klinik Laras Hati Sewon Bantul

Subjek dan Metode: Jenis penelitian ini adalah dekriptif dengan pendekatan kualitatif, Penelitian di lakukan di Klinik Laras Hati. Subyek Penelitian ini dilakukan kepada petugas rekam medis Klinik Laras Hati

Hasil Penelitian : Jumlah waktu yang tersedia adalah 1855 jam/tahun. Unit kerja yang tersedia adalah pendaftaran dan penyimpanan, standar beban kerja pendaftaran pasien adalah 19946,2366 menit, beban kerja pengambilan berkas rekam medis adalah 327352,941 menit, dan beban kerja penegmbalian berkas rekam medis adalah 18500 menit, standar kelonggaran adalah 0,01, dan kebutuhan tenaga rekam medis di bagia pendaftaran 2 orang dan bagian filing 2 orang.
\end{abstract}

Kesimpulan : kebutuhan tenaga rekam medis di klinik laras hati adalah sebayak 4 tenaga rekam medis

Kata Kunci : $\quad$ Analisis, Beban Kerja, Rekam Medis, WISN

\begin{abstract}
Background: Workload Analysis is an effort to calculate workload on work units by adding up all workloads and then dividing by work capacity per person per unit time. Klinik Laras Hati Sewon Bantul has not had DIII Medical Record graduates, so the clinic needs to calculate and hold a medical record officer at the Laras Hati Clinic using the WISN Method.

The Purposes: The purpose of this study was to determine the needs of Medical Record Personnel in the Klinik Laras Hati Sewon Bantul

Subjects and Methods: This type of research is descriptive with a qualitative approach, the study was conducted at the Klinik Laras Hati. The subject of the research was the medical record officer Klinik Laras Hati Research Results: The amount of time available is 1855 hours / year. Available work units are registration and storage, the standard workload for patient registration is 19946.2366 minutes, the workload for receiving medical records is 327352,941 minutes, and the workload for managing medical records is 18500 minutes, the allowance standard is 0.01 , and the need for medical record personnel in 2 people registration and 2 people submission section.
\end{abstract}

Conclusion: the need for medical record personnel in the heart barrel clinic is as much as 4 medical record personnel

Keywords: Analysis, Workload, Medical Records, WISN 


\section{PENDAHULUAN}

Menurut Undang-Undang RI Nomor 36 tahun 2014 tentang tenaga kesehatan, Tenaga kesehatan adalah setiap orang yang mengabdikan diri dalam bidang kesehatan serta memiliki pengetahuan dan/atau keterampilan melalui pendidikan di bidang kesehatan yang untuk jenis tertentu memerlukan kewenangan untuk melakukan upaya kesehatan. Tenaga Rekam Medis dan manajemen Informasi Kesehatan merupakan salah satu tenaga yang bekerja di fasilitas pelayanan kesehatan akan tetapi termasuk dalam kelompok tenaga keteknisian medis. Tugas dan tanggung jawab petugas rekam medis dan manajemen informasi kesehatan adalah mengumpulkan, mengolah, dan menyimpan data pasien menjadi informasi yang digunakan sebagai salah satu instrument dalam pengambilan keputusan Di Indonesia sendiri kebutuhan akan tenaga rekam medis dan informasi kesehatan sangat tinggi hal tersebut dikarenakan jumlah antara kebutuhan tenaga rekam medis di fasilitas pelayanan kesehatan dengan jumlah lulusan yang tersedia tidak seimbang sehingga banyak fasilitas pelayanan kesehatan yang jumlah kebutuhan tenaga rekam medisnya tidak dapat terpenuhi. Atas permasalahan tersebut banyak fasilitas pelayanan kesehatan kemudian mengambil keputusan untuk merekrut petugas yang berkerja di fasilitas pelayanan kesehatan adalah lulusan dari bidang keilmuan yang lainnya bukan dari bidang keilmuan rekam medis dan manajemen infromasi kesehatan.

Menurut Kepmenkes No.81 tahun 2004, Analisis beban kerja adalah upaya menghitung beban kerja pada satuan kerja dengan cara menjumlah semua beban kerja dan selanjutnya membagi dengan kapasitas kerja per orangan per satuan waktu. Analisis beban kerja ini digunakan oleh petugas rekam medis untuk menghitung kebutuhan tenaga rekam medis di suatu unit, sehingga dapat dijadikan sebagai bahan acuan dalam proses perencanaan. Perencanaan kebutuhan di rumah sakit harus melihat dari segi kebutuhan, kualifikasi, dan pengadaannya. kelebihan jumlah sumber daya manusia dapat menyebabkan ketidakefektifan dan ketidakefisienan dan menyebabkan pemborosan dari berbagai segi. Kekurangan sumber daya manusia juga dapat menyebabkan beban pekerjaan yang tinggi. Sehingga ketika melakukan analisis beban kerja harus memperhatikan dari segi kebutuhan, kualifikasi, dan pengadaan.

Klinik Larashati berada di lokasi yang cukup strategis, yaitu sekitar 100m masuk dari di Jl. Parangtritis Km.6, Sewon, Bantul. Posisi klinik ini berada di antara dua kampus, yaitu kampus ISI dan kampus STIKes AKBIDYO dengan lingkungan bangunan yang cukup padat berupa pemukiman penduduk. Pemukiman ini selain berupa tempat tinggal penduduk setempat, juga merupakan lokasi tempat kost dan kontrakan mahasiswa kedua kampus tersebut. Lokasi klinik ini termasuk di dalam lingkungan desa Panggungharjo, kecamatan Sewon Kabupaten Bantul, Daerah Istimewa Yogyakarta, yang pada sebelah utara desa berbatasan langsung dengan kota Yogyakarta. Klinik Laras Hati mempunyai Unit Khusus dalam mengolah dan menyimpan data dan berkas rekam medis. Berdasarkan hasil studi pendahuluan yang telah peneliti lakukan di Klinik Laras Hati mendapatkan bahwa Klinik Laras Hati belum memiliki lulusan rekam medis dan manajemen informasi kesehatan untuk mengumpulkan, mengolah dan menyimpan data pasien. Sedangkan dalam aturan UU praktik kedokteran menyatakan bahwa setiap dokter yang menyelenggarakan praktik kedokteran wajib membuat rekam medis, dan yang mengumpulkan, mengolah, dan menyimpan data rekam medis adalah petugas rekam medis dengan pendidikan minimal DIII Rekam Medis. Berdasarkan Latar Belakang tersebut Peneliti dan tim tertarik untuk melakukan penelitian dengan judul "Analisis kebutuhan Petugas Rekam Medis di Klinik Laras Hati Sewon Bantul”.

\section{TUJUAN}

Penelitian ini bertujuan untuk Mengetahui kebutuhan Tenaga Rekam Medis di Klinik Laras Hati Sewon Bantul.

\section{SUBJEK DAN METODE}

Jenis penelitian yang digunakan dalam penelitian ini adalah deskriptif dengan pendekatan kualitatif,. penelitian ini dilaksanakan selama 2 bulan terhitung mulai 
bulan Oktober 2019 sampai dengan November 2019 yang dilakukan di Klinik Laras Hati.

Subyek yang diikutsertakan dalam penelitian ini diantaranya petugas rekam medis Klinik Laras Hati. Tahapan-tahapan yang dilakukan dalam melakukan penelitian diantaranya tahapan persiapan (membuat surat ijin studi pendahuluan, membuat proposal penelitian, mengajukan proposal ke unit BPPKM STIKes AKBIDYO untuk mendapatkan persetujuan dan biaya penelitian), tahap pelaksanaan (mencari data dengan cara melakukan observasi, wawancara, dan studi dokumentasi di Klinik Laras Hati), Tahap Penyelesaian (pembuatan laporan akhir yang disusun berdasarkan sistematika yang ada di STIKes AKBIDYO.

Etika dalam melakukan penelitian ini dilakukan dengan cara menyampaikan dan menjelaskan kepada kepala klinik dan pegawai unit rekam medis tentang maksud dan tujuan dilakukannya penelitian ini. Setalah informasi tersebut tersampaikan kemudian peneliti dan tim mengumpulkan data dengan cara melakukan observasi terhadap waktu lama pelayanan yang diberikan patugas rekam medis dalam memberikan pelayanan kepada pasien. Setelah data terkumpulkan kemudian peneliti dan tim menghitung kebutuhan jumlah tenaga rekam medis dan manajemen infromasi kesehatan di klinik laras hati. Hasil dari penelitian ini kemudian di sampaikan kepada kepala klinik laras hati sebagai masukan apabila akan melakukan recruitment pegawai rekam medis dan infromasi kesehatan.

\section{HASIL}

\section{Menghitung waktu kerja tenaga rekam medis di Klinik Laras Hati Sewon Bantul}

Berdasarkan hasil perhitungan waktu kerja yang tersedia di Klinik Laras Hati Sewon Bantul dengan memperhatikan Hari Kerja (A), Cuti Tahunan (B), Pendidikan dan Pelatihan (C), Hari Libur Nasional (D), Ketidakhadiran kerja (E), Waktu kerja dalam 1 hari (F) dan menggunakan rumus sebagai berikut:

Waktu kerja tersedia adalah $=\mathrm{A}-(\mathrm{B}+\mathrm{C}+\mathrm{D}+\mathrm{E}) \mathrm{x} \mathrm{F}$
Dihasilkan bahwa waktu kerja yang tersedia di unit rekam medis Klinik Laras Hati adalah 1855 jam/tahun atau 111300 menit/tahun atau 6678000 detik/tahun

2. Menetapkan unit kerja dan kategori Sumber Daya Manusia di Klinik Laras Hati Sewon Bantul

Unit kerja rekam medis di Klinik Laras Hati Sewon Bantul terdiri dari bagian pendaftaran dan bagian penyimpanan. Bagian pendaftaran di bagi menjadi 2 bagian yaitu pendaftaran rawat jalan dan pendaftaran rawat inap, dan bagian penyimpanan/ filing dibagi menjadi 2 pekerjaan yaitu penyimpanan berkas rekam medis, dan pengembalian berkas rekam medis

\section{Menghitung standar beban kerja tenaga rekam medis di Klinik Laras Hati Sewon Bantul}

Dalam menghitung standar beban kerja tenaga rekam medis di Klinik Laras Hati Sewon bantul dibutuhkan pula data waktu kerja yang tersedia dan rata-tata kegiatan pokok. Perhitungan standar beban kerja ini menggunakan metode WISN yaitu sebagai berikut

Standar Beban Kerja $=\frac{\text { Waktu Kerja tersedia }}{\text { Rata-rata kegiatan pokok }}$

Berdasarkan hasil perhitungan standar beban kerja tenaga rekam medis di Klinik Laras Hati Sewon Bantul menunjukkan standar beban kerja pengambilan berkas $\mathrm{Rm}$ adalah 18500, pengembalian berkas RM adalah 327352,941, dan pendaftaran pasien adalah 19946,2366

\section{Menghitung standar kelonggaran tenaga rekam medis di Klinik Laras Hati Sewon Bantul}

Faktor kelonggaran merupakan kegiatan yang tidak berkaitan dengan pelayanan terhadap pasien secara langsung atau merupakan waktu yang digunakan untuk melaksanakan kegiatan diluar kegiatan pokok seperti rapat, akan tetapi menjadi beban kerja bagi petugas yang ada di unit kerja tersebut. Adapun perhitungan standar kelonggaran yang digunakan di Klinik Laras Hati Sewon Bantul adalah sebagai berikut: 


\begin{tabular}{|c|c|}
\hline \multirow{2}{*}{$\begin{array}{l}\text { Standar } \\
\text { Kelonggaran }=\end{array}$} & $\begin{array}{l}\text { Rata-rata waktu per-fakto } \\
\text { kelonggaran }\end{array}$ \\
\hline & waktu ke \\
\hline
\end{tabular}

Berdasarkan hasil perhitungan standar kelonggaran tenaga rekam medis di Klinik Laras Hati Sewon Bantul adalah 0,01 jam/tahun

\section{Menghitung kebutuhan tenaga per unit rekam medis di Klinik Laras Hati Sewon Bantul}

Untuk menghitung kebutuhan tenaga rekam medis di Klinik Laras Hati Sewon Bantul, diperlukan data kuantitas kegiatan pokok, standar beban kerja, dan standara kelonggaran.

Perhitungan kebutuhan SDM (tenaga rekam medis Klinik Laras Hati) ini menggunakan metode WISN yaitu:

\begin{tabular}{lll} 
& Kuantitas & \\
Kebutuhan & Kegiatan & \\
SDM $=$ & Pokok & \\
\cline { 2 - 3 } & Standar & + \\
& BebanKerja & Standar Kelonggaran
\end{tabular}

Adapun kebutuhan tenaga rekam medis di Klinik Laras Hari adalah sebagai berikut:

1. Kebutuhan tenaga pengambilan berkas $\mathrm{Rm}$ adalah 1 orang

2. Kebutuhan tenaga pengembalian berkas RM adalah 1 orang petugas

3. Kebutuhan bagian pendaftaran pasien adalah 2 orang petugas

\section{PEMBAHASAN}

1. Menghitung waktu kerja tenaga rekam medis di Klinik Laras Hati Sewon Bantul Menurut Kepmenkes No 81 tahun 2004 tentang Pedoman Penyusunan Perencanaan Sumber Daya Manusia Kesehatan di Tingkat Propinsi, Kabupaten/Kota, serta Rumah Sakit. dengan rata-rata 8 jam/shift. Berdasarkan hasil perhitungan waktu kerja tersedia di unit rekam medis Klinik Laras Hati Sewon Bantul adalah $1855 \mathrm{jam} /$ tahun atau 111300 menit/tahun dan waktu kerja 7 jam/hari. Hal tersebut disebabkan jumlah hari kerja 5 hari/minggu dikarenakan hari Sabtu dan Minggu serta hari libur ikut libur.

2. Menetapkan unit kerja dan kategori Sumber Daya Manusia di Klinik Laras Hati Sewon Bantul

Menurut Budi (2011) ruang lingkup unit kerja rekam medis dimulai dari penerimaan pasien, distribusi, assembling, pengkodean (coding), pengindekan (indexing), penyimpanan (filing), dan pelaporan. Klinik Laras Hati mempunyai Unit rekam medis yang dimana unit tersebut melaksanakan beberapa aktivitas pekerjaan antara lain adalah pendaftaran yang terbagi atas pendaftaran rawat jalan dan pendaftaran rawat inap, dan kegiatan penyimpanan berkas rekam medis yang terdiri atas pengambilan berkas rekam medis dan pengembalian berkas rekam medis. Setiap kegiatan yang ada di unit rekam medis telah dibagai sesuai dengan kompetensinya dan berpedoman kepada SOP ada. Akan tetapi pada kenyataan yang ada dilapangan masih ada petugas yang merangkap pekerjaan diluar uraian tugasnya. Hal tersebut mengacu pada peraturan Kepmenkes No 81 tahun 2004 Menetapkan unit kerja dan kategori SDM tujuannya adalah diperolehnya unit kerja dan kategori SDM yang bertanggung jawab dalam menyelenggarakan kegiatan pelayanan kesehatan perorangan pada pasien, keluarga dan masyarakat di dalam dan diluar rumah sakit.

Petugas yang mempunyai uraian tugas di klinik laras hati adalah semua petugas yang bekerja di klinik laras hati dengan menggunakan metode system rooling, setiap bidan dan tenaga kesehatan lainnya mendapat jatah untuk bekerja di unit rekam medis. Berdasarkan latar belakag pendidikan petugas yang bekerja di unit rekam medis, tidak ada petugas yang mempunyai latar belakang pendiikan D3 rekam medis atau sarjana terapan manajemen informasi kesehatan. Hal tersebut belum mengacu pada Permenkes No. 55 tahun 2013 yang mengatakan bahwa perekam medis adalah seseorang yang telah lulus pendidikan rekam medis dan informasi kesehatan yaitu minimal D3 Rekam medis sesuai ketentuan peraturan perundang-undangan dan telah memiliki SIK atau STR).

3. Menghitung standar beban kerja tenaga rekam medis di Klinik Laras Hati Sewon Bantul 
Berdasarkan hasil perhitungan standar beban kerja yang telah dilakukan peneliti dan tim diketahui bahwa standar beban kerja pengambilan berkas rekam medis adalah 18500 menit, standar beban kerja pengembalian berkas rekam medis adalah 327352,941 menit, dan standar beban kerja pendaftaran pasien adalah 19946,2366 menit. Apabila dilihat standar bean kerja yang membutuhkan waktu kerja tertinggi adalah pengembalian berkas rekam medis. Hal tersebut mengacu pada teori Kepmenkes no. 81 tahun 2004 tentang standar beban kerja disebutkan bahwa standar beban kerja disusun berdasarkan waktu kerja tersedia per-tahun dan rata-rata waktu yang dibutuhkan untuk menyelesaikan kegiatan yang dimilki oleh masing-masing tenaga.

\section{Menghitung standar kelonggaran tenaga rekam medis di Klinik Laras Hati Sewon Bantul}

Menurut Kepmenkes No 81 tahun 2004 tentang Pedoman Penyusunan Perencanaan Sumber Daya Manusia Kesehatan di Tingkat Propinsi, Kabupaten/Kota, serta Rumah Sakit faktor kelonggaran meliputi jenis kegiatan dan kebutuhan waktu untuk menyelesaikan suatu kegiatan yang tidak terkait langsung atau dipengaruhi tinggi/rendahnya kualitas kegiatan atau jumlah kegiatan/pelayanan. Contoh faktor kelonggaran adalah rapat, penyusunan laporan, pengebonan barang, frekuensi kegiatan dalam suatu hari/minggu/bulan, waktu yang dibutuhkan untuk menyelesaikan kegiatan.

Berdasarkan hasil perhitungan yang telah peneliti dan tim lakukan di unit rekam medis Klinik Laras Hati di ketahui bahwa standar kelonggaran di unit rekam medis adalah 0,01. Standar kelonggaran tersebut adalah rapat rutin yang dilakukan setiap bulannya selama 1 tahun

\section{Menghitung kebutuhan tenaga per unit rekam medis di Klinik Laras Hati Sewon Bantul}

Berdasarkan hasil perhitungan kebutuhan sumberdaya manusia yang telah peneliti dan tim lakukan, diketahui bahwa unit rekam medis klinik laras hati membutuhkan 4 orang petugas rekam medis dengan latar belakang pendidikan D3 rekam medis dan sarjana terapan manajemen informasi kesehatan yang telah mempunyai STR sebagai bukti kompetensi lulusan rekam medis. 4 petugas tersebut terbagi kedalam beberapa bagian diantaranya adalah 2 petugas pendaftaran, 1 petugas pengambilan berkas rekam medis, dan 1 petugas pengembalian berkas rekam medis. Hal tersebut senada dengan hasil perhitngan yang telah dilakukan oleh Parmita (2017) menghasilkan perhitungan kebutuhan tenaga rekam medis pada bagian pendaftaran adalah 2 petugas.

\section{KESIMPULAN}

Berdasarkan hasil penelitian maka dapat disimpulkan bahwa:

1. Jumlah waktu kerja tersedia di Klinik Laras Hati adalah 1855 jam/tahun, 111300 menit/tahun, atau 6678000 detik/tahun.

2. Unit kerja di Klinik Laras Hati Sewon Bantul adalah unit rekam medis bagian pendaftaran dan penyimpanan berkas rekam medis

3. Standar beban kerja tenaga rekam medis di bagian pendaftaran dan penyimpanan adalah beban kerja pendaftaran pasien adalah 19946,2366 menit, beban kerja pengambilan berkas rekam medis adalah 327352,941menit, dan beban kerja penegmbalian berkas rekam medis adalah 18500 menit

4. Standar Kelonggaran tenaga rekam medis di Klinik Laras Hati Sewon Bantul adalah 0,01

5. Standar kebutuhan tenaga rekam medis di Klinik Laras Hati Sewon Bantul adalah bagian pendaftaran membutuhkan 2 petugas rekam medis, dan bagian penyimpanan/filing membutuhkan 2 petugas rekam medis (pengambilan berkas rekam medis 1 petugas rekam medis dan pengembalian berkas rekam medis 1 petugas rekam medis)

\section{DAFTAR PUSTAKA}

Abdullah, NF. 2016. Analisis Kebutuhan Tenaga dengan Metode Workload Indicator Staffing Need (WISN) pada Instansi Rekam Medis RSUD Sultan Imanuddin Pangkalan BUN. Surakarta: Universitas Muhammadiyah.

Azwar, S .2014. Metode Penelitian. Yogyakarta: Pustaka Pelajar. 
Kemenkes RI. 2011.Permenkes RI No 028 Tahun 2011 Tentang Klinik. Jakarta: Depkes RI.

Kemenkes RI. 2014. Permenkes RI Nomor 9 Tahun 2014 Tentang Klinik. Jakarta:Depkes RI

Menteri Kesehatan RI. 2004. Keputusan Menteri Kesehatan Republik Indonesia Nomor 81/MENKES/SK/I/2004 Tentang Pedoman Penyusunan Perencanaan Sumber Daya Manusia Kesehatan di Tingkat Propisi, Kabupaten/Kota serta Rumah Sakit . Jakarta: Menteri Kesehatan Republik Indonesia.

Moleong, LJ. 2010. Metodologi Penelitian Kualitatif. Bandung: Remaja Rosda Karya.

Munandar, A. 2014. Analisis Kebutuhan SDM berdasarkan Bebak Kerja dengan Metode WISN (Workload Indicator Staffing Need) di Unit Kerja Rekam Medis RSUD Prambanan Tahun 2012. Yogyakarta: Universitas Gadjah Mada.
Parmita, AR 2017. Perhitungan kebutuhan tenaga rekam medis dengan metode wisn (workload indicator staffing need) di RS dr. Soetarto yogyakarta tahun 2016. Yogyakarta. STIKES A.Yani Yogyakarta

Peraturan Pemerintah Republik Indonesia Nomor 15 Tahun 2007 tentang Tata Cara Memperoleh Informasi Ketenagakerjaan dan Penyusunan serta Pelaksanaan Perencanaan Tenaga Kerja

Permendagri.2008. Peraturan Menteri Dalam Negeri Nomor 12 Tahun 2008 tentang Pedoman Analisis Beban Kerja Di Lingkungan Departemen Dalam Negeri Dan Pemerintah Daerah.

Undang-Undang Republik Indonesia Nomor 36 Tahun 2009 Tentang Kesehatan.

Undang-Undang Republik Indonesia Nomor 44 Tahun 2009 Tentang Rumah Sakit 